\title{
Phytochemical Status of Different Solvent Extracts of Anthocleista djalonensis $A$. Chev Leaves
}

\author{
Popoola, Oluwaseyi O. \\ Forestry Research Institute of Nigeria. P.M.B 5054, Jericho hills, Ibadan, Oyo State. Nigeria \\ * Corresponding author email: oluseyi.popoola@gmail.com
}

Received: 13 June 2019 / Revised: 09 August 2019 / Accepted: 19 August 2019 / Published: 30 August 2019

\begin{abstract}
The choice of suitable solvent is essential in the extraction of much needed bioactive phytochemicals present in medicinal plants. This study assessed the phytochemical status of four solvents (methanol, hexane, ethylacetate and aqueous) extracts of Anthocleista djalonensis, leaves of the plants were extracted with the solvents by cold maceration for three days; screening and quantitative determination of saponin, alkaloid, tannin, cardiac glycosides, flavonoids phenols and terpenoids was done using standard methods. Phytochemical screening indicates the presence of all the phytocompound in the methanol extract, while other extracts shows variation in the availability of different phytochemicals, quantitative results shows alkaloid ranged from $1.79-18.90 \mathrm{mg} / 100 \mathrm{~g}$, flavonoids: $2.54-10.53 \mathrm{mg} / 100 \mathrm{~g}$, saponin: $2.00-12.23 \mathrm{mg} / 100 \mathrm{~g}$, tannin: ND-4.83 mg/100g, phenol: ND-6.65 mg/100g, cardiac glycoside: ND-2.08 mg/100g, and terpenoids: ND-1.98 mg/100g; significant difference $(\mathrm{p}<0.05)$ exist in each phytochemicals across the solvents where methanol and the aqueous extracts gave the best extraction efficiency for the phytochemicals. Consequently, the optimum extraction of useful phytochemicals from $A$. djalonensis could be achieved using either methanol and water.
\end{abstract}

Keywords: Anthocleista djalonensis, Phytochemicals, Methanol, Hexane, Ethylacetate, Aqueous

\section{Introduction}

Phytochemicals are naturally occurring substances present in plants [1], these substances have been found to be beneficial to human health as well as possessing antioxidant activity [2] some plants based nutraceuticals and herbs have potent phytochemical constituents that can help to promote healthy living. Phytochemical can also help in the protection against many diseases related to diets. Many pharmaceutical based businesses have identified the role of plants in sourcing for pharmacological compounds because they have immense medicinal properties [3]; secondary metabolites that are of great importance include flavonoids, tannins, alkaloids, phenols, saponins, terpenoids and cardiac glycosides are from plants [4]. Each of the secondary metabolites possess explicit function such as antifungal action of saponin [5], antimicrobial activity of tannin [6], usefulness of certain alkaloids for the treatment of HIV infection [7], potent anti-cancer activity of flavonoids [8]. Medicinal plants extensively occur globally and now it's getting more consideration because they have several beneficial properties to all human beings especially in pharmacological and medicine field. These plants have medicinal valuable phytochemical components that produce pharmacological response in living creatures. Anthocleista djalonensis is one of such medicinal plant rich in valuable phytocompounds that elicits widely reported pharmacological response. Anthocleista djalonensis A. Chev. is a member of the family Gentianaceae and formerly Loganiaceae, it has a common name called 
Cabbage tree; Anthocleista are trees and shrub like plants in the major group of Angiosperms [9]. It is called Sapo in Yoruba, Kwarii in Hausa, Okpokolo in Igbo and Osuo in Bayelsa state in southern Nigeria and it is wide spread in West Africa. It grows as a small tree and reaches stature heights of up to $15 \mathrm{~m}$ Its slender trunk has a diameter of $40 \mathrm{~cm}$. The opposite and regularly set leaves are divided into petiole and leaf blade; the petiole is 1 to $9 \mathrm{~cm}$ long while the leaf blade is simple, elongated, elliptical to obovate-elliptic having a length of 9 to $35 \mathrm{~cm}$ in young plants of $115 \mathrm{~cm}$ and 5 to $17 \mathrm{~cm}$ width, the young plants width is about $50 \mathrm{~cm}$ with a heart-shaped, plump or wedge-shaped base, wedge-shaped upper end and a smooth edge [10]. A. djalonensis is extensively used for diverse disorders in Nigeria, it is utilized as a remedy for stomach complaint, as a laxative and antipyretic substance. It is also reportedly used in the management of liver problems, as analgesic, treatment of swellings, dropsy, oedema and as antidote to poisonous bites and stings. Other acknowledged ethnomedicinal applications of the extract of $A$. djalonensis plants parts (roots, stem and leaves) are wound treatment, abdominal pain, skin boils and fungal skin infection, acute inflammation, jaundice, filarial worm infections, hepatitis, constipation dysentery and diarrhoea among others [11-13]. Maximising the potential of any plant for medicinal purposes starts with the extraction of useful phyto-compounds in the plant using appropriate extracting agent, thus, the extraction of secondary metabolites is a crucial process in the detection of substances that are biologically active in medicinal plants [14]. Various studies have shown that no single solvent can adequately extract most bioactive components present in plants. Thus, the optimum extraction of secondary metabolites from medicinal plants are important target during research for drug development; the existence of phytochemicals of diverse polarities and structures bring about the use of an array of solvents for extraction. The objective of this study is to determine the phytochemical status of A. djalonensis leaves extracted with four solvents (methanol, aqueous, hexane and ethylacetate).

\section{Materials and Method}

\subsection{Sample Collection and Preparation}

The leave samples were collected from the premises of Forestry Research Institute of Nigeria. The Identification of the plants species was done at the taxonomy department of the institute. The freshly collected leaves were air dried at room temperature, and then blend to powder with laboratory mortar and pestle, then stored in an airtight vessel until needed.

\subsection{Sample Extraction}

$100 \mathrm{~g}$ of powdered sample was soaked in $400 \mathrm{ml}$ each of methanol, hexane, ethyl acetate and distilled water (aqueous) for 3 days with constant agitation, the mixture was separated using Whatman filter paper No. 1, this was followed by the concentration of each filtrate under vacuum with rotary evaporator to reduce the solvent volume and obtain extracts for qualitative and quantitative phytochemical analysis.

\subsection{Phytochemical Estimation}

Screening for phytochemicals was done on the respective extracts of $A$. djalonensis using standard procedures to identify phytochemical constituents (alkaloids, tannins, flavonoids, saponins, terpenes, phenols, cardiac glycoside) as described by Harborne [15]; quantitative estimation was done using the methods of Mbaebie et al. [16].

\subsubsection{Qualitative Phytochemical Screening}

\subsubsection{Test for Saponin}

Saponin presence was tested using the frothing test. Distilled water $(10 \mathrm{ml})$ was used to dilute 5 $\mathrm{ml}$ of each extract, this was agitated vigorously for about 10 minutes and observed for foaming. The presence of saponin was identified with persistent foaming.

\subsubsection{Test for Alkaloid}

Alkaloid was ascertained using the Dragendorff, Meyer and Wagner's reagents. The extract $(0.2 \mathrm{mg})$ was introduced into dilute $\mathrm{HCl}(6 \mathrm{ml})$, the mixture was boiled, cool and filtered. The filtrate was shared into three portions. 
Popoola Oluwaseyi O, Int. Ann. Sci.; Vol. 8, Issue 1, pp: 62-69, 2020

Dragendorff's reagent ( 2 drops) was put to the first portion where the development of a red precipitate is indicative that alkaloid is present; Meyer's reagent (2 drops) was added to the second portion, where a creamy white precipitate reveals the presence of alkaloids; Wagner's reagent ( 2 drops) was put to the third portion where a reddish brown precipitate suggests that alkaloid is present.

\subsubsection{Test for Tannins}

The presence of tannin was determined by mixing distilled water of $10 \mathrm{ml}$ with $1 \mathrm{ml}$ of respective extracts, this was then followed by addition of 3 drops of $\mathrm{FeCl}_{3}$ where the appearance of a greenish brown precipitate is indicative of tannin.

\subsubsection{Test for Flavonoids}

Flavonoid's presence was determined by boiling a little portion of the respective extracts in $10 \mathrm{ml}$ of ethylacetate for about 3 minutes, then filtration and cooling of the filtrate after which $1 \mathrm{ml}$ of dilute $\mathrm{NH}_{3}$ solution was shaken with $4 \mathrm{ml}$ of the respective filtrate. The formation of an intense yellow colour indicates the presence of flavonoids

\subsubsection{Test for Terpenoids}

Terpenoids in the respective extracts was tested by refluxing the mixture of $1 \mathrm{ml}$ of respective extracts and $9 \mathrm{ml}$ of ethanol for few minutes, the solution was filtered and the volume was reduced to $2.5 \mathrm{ml}$ in a boiling water bath, then $5 \mathrm{ml}$ of hot distilled water was introduced into the solution, with the mixture allowed to sit for an hour, then the waxy matter filtered off. The filtrate extraction was carried out with chloroform (2.5 $\mathrm{ml}$ ) in a separating funnel, with the chloroform extract evaporated to dryness and dissolved in conc. $\mathrm{H}_{2} \mathrm{SO}_{4}$ and then heated for about 10 minutes. The formation of a grey colouration is indicative of terpenoids.

\subsubsection{Test for Phenols}

Phenols was done by dissolving $1 \mathrm{ml}$ of the respective solvent extract of distilled water $(5 \mathrm{ml})$, then few drops of $5 \% \mathrm{FeCl}_{3}$ was added where a bluish black or greenish colouration brown precipitate is indicative of phenols.

\subsubsection{Test for Cardiac glycosides}

Cardiac glycoside was done with $1 \mathrm{ml}$ of the respective solvent extracts mixed in a test tube with dilute $\mathrm{H}_{2} \mathrm{SO}_{4}$ and then boiled for 15 minutes, the mixture was cooled followed by neutralization of the acid with $20 \% \mathrm{NaOH}$ solution; a mixture $(10 \mathrm{ml})$ of Fehling's solution. $\mathrm{A}$ and $\mathrm{B}$ was introduced followed by boiling for 5 minutes. Brick red precipitate reveals cardiac glycoside.

\subsubsection{Quantitative Phytochemical Analysis}

\subsubsection{Determination of Saponins}

The extracts $(0.5 \mathrm{~g})$ were soaked with petroleum ether $(10 \mathrm{ml})$ and decanted into a beaker. $10 \mathrm{ml}$ of petroleum ether was added into the beaker and the filtrate evaporated into dryness. Residue was solubilized in ethanol (6ml). The solution (2 ml) was put in a test tube and $2 \mathrm{ml}$ of chromagen solution added into it. The mixture was left for 30 minutes; after $550 \mathrm{~nm}$ the absorbance measured.

\subsubsection{Determination of Alkaloids}

The extracts $(0.5 \mathrm{~g})$ were macerated with ethanol $(20 \mathrm{ml})$ and $20 \% \mathrm{H}_{2} \mathrm{SO}_{4}(1: 1 \mathrm{v} / \mathrm{v}) .1 \mathrm{ml}$ of the filtrate was added with $5 \mathrm{ml}$ of $60 \% \mathrm{H}_{2} \mathrm{SO}_{4}$ and the mixture was let to sit for 5 minutes after which $5 \mathrm{ml}$ of $0.5 \%$ formaldehyde in $60 \% \mathrm{H}_{2} \mathrm{SO}_{4}$ was mixed with the mixture and left to stay for 3 $\mathrm{hr}$, the absorbance reading was taken at $565 \mathrm{~nm}$.

\subsubsection{Determination of Tannins}

The extracts $(0.5 \mathrm{~g})$ were soaked with methanol $(50 \mathrm{ml})$ and filtered. To the filtrate $(5 \mathrm{ml}), 0.3 \mathrm{ml}$ of $0.1 \mathrm{~N}$ ferric chloride in $0.1 \mathrm{~N} \mathrm{HCl}$ and $0.3 \mathrm{ml}$ of $0.0008 \mathrm{M}$ of potassium ferricyanide were added and the absorbance read at $720 \mathrm{~nm}$.

\subsubsection{Determination of Flavonoids}

The extracts $(0.5 \mathrm{~g})$ were macerated with $20 \mathrm{ml}$ of ethylacetate for $5 \mathrm{~min}$ and filtered, then $5 \mathrm{ml}$ of the filtrate was added with dilute $\mathrm{NH}_{3}$ and the mixture shaken for $5 \mathrm{~min}$. The upper layer was collected and the absorbance taken at $490 \mathrm{~nm}$. 


\subsubsection{Determination of Terpenoids}

The extracts $(0.5 \mathrm{~g})$ were macerated with $50 \mathrm{ml}$ of ethanol, filtered, then, $2.5 \mathrm{ml}$ of the filtrate was added with $2.5 \mathrm{ml}$ of the aqueous solution of $5 \%$ phosphomolybdic acid, followed by the gradual addition of $2.5 \mathrm{ml}$ of concentrated $\mathrm{H}_{2} \mathrm{SO}_{4}$. The mixture after mixing was left to stay for $30 \mathrm{~min}$ after which it was made up to $12.5 \mathrm{ml}$ with ethanol. The absorbance was taken at $700 \mathrm{~nm}$.

\subsubsection{Determination of Cardiac Glycosides}

Extracts $(0.5 \mathrm{~g})$ were soaked with distilled water $(50 \mathrm{ml})$ and filtered, then, $4 \mathrm{ml}$ of alkaline solution was added to the filtrate $(1 \mathrm{ml})$. The mixture was boiled for 5 min and cooled. The absorbance was read at $490 \mathrm{~nm}$.

\subsubsection{Determination of Phenols}

The extracts $(0.5 \mathrm{~g})$ were macerated with $20 \mathrm{ml}$ of $80 \%$ ethanol and then filtered. The filtrate $(5 \mathrm{ml})$ was mixed with $0.5 \mathrm{ml}$ of folin ciocalteus reagent and left to sit for $30 \mathrm{~min}$. Then, $2 \mathrm{ml}$ of $20 \%$ sodium carbonate was added and absorbance measured at $650 \mathrm{~nm}$.

\subsection{Statistical analysis}

SPSS version 20 was used for the statistical analysis, quantitative phytochemicals were presented as mean $\pm S D$ of triplicate measurement; analysis of variance (ANOVA) was used to detect test for significant differences between the mean of the phytochemicals in the different solvent extracts, while Least Significant Difference (LSD) post hoc test was done to separate means, p-value less than 0.05 was considered significant.

\section{Results}

The result in Table 1 shows the qualitative phytochemical screening of four extract of $A$. djalonensis which are methanol extract, hexane extract, ethylacetate extract and aqueous extract and the phytochemicals examined includes; saponin, flavonoids, terpenoids, phenols, tannin, alkaloids, and cardiac glycosides. Saponin, flavonoids and alkaloids are present in all the extracts used. Phenols, tannin, terpenoids, and cardiac glycosides were not extracted by hexane solvents. Also, terpenoids, phenol and cardiac glycosides were not present in the ethylacetate solvent extractions. Aqueous extract shows the presence of all the phytochemicals except terpenoids, while methanol was able to extract all the phytochemicals examined.

Table 1: Result showing Qualitative phytochemical screening of the leaves of Anthocleista djalonensis

\begin{tabular}{|c|c|c|c|c|c|}
\hline Phytochemical Test & Observation & ME & HE & $\mathbf{E E}$ & $\mathbf{A E}$ \\
\hline $\begin{array}{c}\text { Saponins } \\
\text { (Frothing test) }\end{array}$ & $\begin{array}{l}\text { Persistence } \\
\text { foaming }\end{array}$ & + & + & + & + \\
\hline $\begin{array}{c}\text { Tannins } \\
\text { (Ferric chloride) }\end{array}$ & $\begin{array}{l}\text { Greenish- } \\
\text { brown } \\
\text { precipitate }\end{array}$ & + & - & + & + \\
\hline $\begin{array}{c}\text { Flavonoids } \\
\text { (Ethylacetate test) }\end{array}$ & $\begin{array}{c}\text { Intense } \\
\text { yellow } \\
\text { colouration }\end{array}$ & + & + & + & + \\
\hline $\begin{array}{c}\text { Terpenoids } \\
\text { (Chloroform and acetic } \\
\text { anhydride test) }\end{array}$ & $\begin{array}{c}\text { A grey } \\
\text { colouration }\end{array}$ & + & - & - & - \\
\hline $\begin{array}{c}\text { Phenols } \\
\text { (Distilled water test) }\end{array}$ & $\begin{array}{c}\text { Blue- } \\
\text { Greenish } \\
\text { colouration }\end{array}$ & + & - & - & + \\
\hline Alkaloid & & & & & \\
\hline $\begin{array}{l}\text { - Dragendorff's } \\
\text { reagent }\end{array}$ & $\begin{array}{l}\text { Red } \\
\text { precipitate }\end{array}$ & + & + & + & + \\
\hline 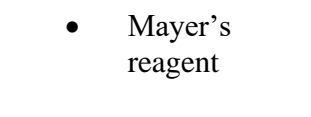 & $\begin{array}{l}\text { Creamy- } \\
\text { white } \\
\text { precipitate }\end{array}$ & + & + & + & + \\
\hline $\begin{array}{l}\text { - Wagners } \\
\text { reagent }\end{array}$ & $\begin{array}{l}\text { Reddish- } \\
\text { brown } \\
\text { precipitate }\end{array}$ & + & + & + & + \\
\hline $\begin{array}{l}\text { Cardiac Glycoside } \\
\text { (Sulphuric acid test) }\end{array}$ & $\begin{array}{l}\text { Brick-red } \\
\text { precipitate }\end{array}$ & + & - & - & + \\
\hline
\end{tabular}

*+-Present, - Absent; Note ME-Methanol Extract, HE- Hexane

Extract, EE-Ethyl-acetate Extract, AE-Aqueous Extract

The quantitative phytochemical analysis (Table 2) clearly indicates variations in the levels of the phytochemicals while some are not detected in a couple of solvents. The highest amount of phytochemical in the study was detected for methanol extract having an alkaloid content of $18.90 \mathrm{mg} / 100 \mathrm{~g}$ while the lowest amount of phytochemical constituent was found also for methanol extract having a cardiac glycoside of $1.09 \mathrm{mg} / 100 \mathrm{~g}$. 
Table 2: Result showing Qualitative phytochemical analysis of the leaves of Anthocleista djalonensis

\begin{tabular}{|c|c|c|c|c|}
\hline \multirow{2}{*}{$\begin{array}{c}\text { Phytochemicals } \\
\mathbf{m g} / 100 g\end{array}$} & \multicolumn{4}{|c|}{$\begin{array}{c}\text { Quantitative Phytochemical } \\
\text { Analysis }\end{array}$} \\
\cline { 2 - 5 } & ME & HE & EE & AE \\
\hline Alkaloid & 18.90 & 1.79 & 5.92 & 8.45 \\
& $\pm 0.89^{\mathbf{d}}$ & $\pm 0.41^{\mathbf{a}}$ & $\pm 0.76^{\mathbf{b}}$ & $\pm 0.72^{\mathbf{c}}$ \\
\hline Flavonoid & 9.73 & 2.54 & 6.12 & 10.53 \\
& $\pm 1.08^{\mathbf{c}}$ & $\pm 0.23^{\mathbf{a}}$ & $\pm 0.30^{\mathbf{b}}$ & $\pm 0.82^{\mathbf{c}}$ \\
\hline Saponin & 5.12 & 2.00 & 3.72 & 12.23 \\
& $\pm 1.06^{\mathbf{b}}$ & $\pm 0.02^{\mathbf{a}}$ & $\pm 0.46^{\mathbf{a}}$ & $\pm 0.65^{\mathbf{c}}$ \\
\hline Tannin & 3.61 & $\mathrm{ND}$ & 2.07 & 4.83 \\
& $\pm 0.45^{\mathbf{a}}$ & & $\pm 0.18^{\mathbf{a}}$ & $\pm 0.80^{\mathbf{b}}$ \\
\hline Phenol & 2.61 & $\mathrm{ND}$ & $\mathrm{ND}$ & 6.65 \\
& $\pm 0.01^{\mathbf{a}}$ & & & $\pm 0.12^{\mathbf{b}}$ \\
\hline Cardiac & 1.09 & $\mathrm{ND}$ & $\mathrm{ND}$ & 2.08 \\
glycosides & $\pm 0.34^{\mathbf{a}}$ & & & $\pm 0.51^{\mathbf{a}}$ \\
\hline Terpenoids & 1.98 & $\mathrm{ND}$ & $\mathrm{ND}$ & $\mathrm{ND}$ \\
& \pm 0.51 & & & \\
\hline
\end{tabular}

*ND-Not Detected, *ME-Methanol Extract, HE- Hexane Extract, EE-Ethyl-acetate Extract, AE-Aqueous Extract. Values with the same alphabets in the same row are not significantly different at $\mathrm{p}<0.05$

\section{Discussion}

Four different types of extracts (Methanol, Hexane, Ethylacetate, and Aqueous) were prepared to test the availability of the Alkaloids, Flavonoids. Saponin, Tannin, Phenol, Cardiac glycosides and Terpenoids. The result reveals the presence of some phytochemical constituents according to the extractive abilities of each solvent. Methanol was able to extract alkaloids, flavonoids, cardiac glycosides saponin, tannin, phenol, and terpenoids while water (Aqueous) extract also contain alkaloids, cardiac glycosides, flavonoids, saponin, tannin, phenol, and terpenoids. Moreover, Alkaloid flavonoid, saponin, and tannin were found in all the solvents' extracts except the hexane extract where tannin was not present. Furthermore, the hexane and ethyl-acetate extract demonstrated the absence of terpenoids, phenol and cardiac glycosides. Lerato et al., [17] reported the presence of all the phytochemicals except alkaloids in their study on the aqueous leave extracts of Tulbaghia violacea, this is similar to the result reported also in this study; alkaloid and phenol are present in aqueous extract which corroborates the work reported by Ajuru, et al., [18] which demonstrated that alkaloid and phenol are present in the aqueous extract of Ocimum canum, Mentha piperita, Ocimum gratissimum.
Saponin derived its name from the formation of stable soapy foam in water solutions, hence, it is typically present in aqueous extracts thereby justifying its presence in this study. This is in line with the result reported by Yaqoob et al., [19] for Ferula Jaeschkeana Vatke leaves where saponin was present in the aqueous extract. Saponin apart from its foaming abilities, also protects against microbial attack in plants; it is helpful in treating yeast and fungal infections [20]. They are also employed in the production of fire extinguisher foam, cosmetics, shampoos, tooth paste, liquid soap, and used in increasing the frothing of beer and soft drinks. The result reported by some authors concerning the screening of saponin in aqueous extracts of some plants is contrary to the result obtained in this study. Anyasor et al., [21] reported the absence of saponin in aqueous and methanolic extract of Costus afer. Similarly, Garg and Garg et al., [22] in their study also showed the absence of saponin in the methanolic extract of Tinospora cordifolia. Studies by Ibrahim et al., [23] shows the presence of some bioactive compounds like tannin, alkaloid, terpenoids, flavonoid and saponin for both methanolic and aqueous extractions for mimosa pudica leaves, this corroborates our findings in this study for $A$. djalonensis. The result obtained for $A$. djalonensis for methanol and aqueous extracts show the presence of phenol, flavonoid and tannin, with the absence of terpenoids and cardiac glycosides in the ethylacetate extract, this is synonymous to the findings of Chigayo et al., [24]. Most of these phytochemicals serve as natural antibiotics, which assist the body in fighting microbial invasion and broad spectrum infections [25]. This shows that medicinal plants harbours potent bioactive compounds capable of preventing and treating most oxidative related diseases [26] and this justifies their usage in traditional medicine [27]. These bioactive compounds seen in plants works with nutrients and dietary fibre to protect against diseases [28]. The alkaloid, flavonoid and saponin contents were significantly different $(p<0.05)$ from each other across the solvents. Methanol and aqueous solvents appeared to extract more phytochemicals than the ethylacetate and hexane solvents. In the methanol extract, alkaloid concentration was the highest 
while cardiac glycosides had the lowest concentration. The actions of alkaloids transcend different metabolic systems in humans, they are said to consistently elicit bitter taste [29], hence, alkaloids are responsible for the bitter taste of leaves and they are capable of reducing headaches related to hypertension [30]. The alkaloid concentrations of all the extracts of the selected solvents were in the range of 1.79-18.90 $\mathrm{mg} / 100 \mathrm{~g}$, the methanol solvent gave the best alkaloid extraction efficiency followed by the aqueous, ethylacetate and hexane solvents. The aqueous extract of $A$. djalonensis had an alkaloid concentration of $8.45 \mathrm{mg} / 100 \mathrm{~g}$ which is more than the alkaloid contents reported to be in some plant like Taraxacom officinale $(1.1 \mathrm{mg} / 100 \mathrm{~g}), C$. asiatica $(0.31 \mathrm{mg} / 100 \mathrm{~g})$, I. cylindrica $(0.45 \mathrm{mg} / 100$ g) [31]. Phenolic compounds are mostly extracted by aqueous solvents and this is also applicable in this study with the aqueous extract of $A$. djalonensis, giving a value of $6.65 \mathrm{mg} / 100 \mathrm{~g}$. Presence of phenol in aqueous extract of $C$. afer was also previously reported [21], likewise, in the results of Lee et al. [32], the most appropriate solvent for phenol extraction in Pleurotus citrinopileatus is aqueous extract, similarly, the maximum level of total phenolic compound in the leaves of Smilax excelsa was seen in the aqueous extracts as reported by Ozsoy et al. [33]. Phenols are considered important because antioxidant naturally comes from plants in the form of phenolic compounds like phenolic acids, flavonoid, etc. Aqueous extract presents the highest value for tannin (4.83 $\mathrm{mg} / 100 \mathrm{~g})$, followed by methanol $(3.614 .83 \mathrm{mg} / 100 \mathrm{~g})$, while the least value was recorded for ethylacetate $(2.074 .83 \mathrm{mg} / 100 \mathrm{~g})$. Plants containing tannins are recognized to have antihelmintic activity [34]. The tannic acid is believed to be a wonderful curative agent, which can be used in neurological diseases [35]. Cardiac glycoside was detected only in aqueous solvent and methanol solvent in comparable levels $(\mathrm{p}<0.05)$. Glycosides are compounds which occurs naturally possessing pharmacological activities such as antitumor, hepatoprotective, antiviral, immunomodulatory, antibacterial, neuroprotective, tyrosinase, antiinflammatory and antioxidant inhibitor activity [36]. The flavonoid concentrations in all the solvents are reasonably high with significant differences $(p<0.05)$ between them, however, the methanol and aqueous solvents extracts have statistically comparable levels. A. djalonensis having been ascertained to possess flavonoid, suggests its beneficial tendency to act as antioxidants in protecting against human diseases like cancer and cardiovascular diseases, viral and bacterial infections, mutagenic activities and the risk of death from coronary heart diseases [37-40] thus, extracting with polar solvent for maximum flavonoid is recognized.

\section{Conclusion}

The phytochemical profiling of $A$. djalonensis shows the presence of some secondary bioactive compounds based on a specific solvent used for extraction. Hence, it is essential to apply the suitable solvents for extractions based on the phytochemicals of interest. Extraction was found to be influenced by the polarity of the various phytochemicals present in the plant. Methanol extract and water extract of $A$. djalonensis gave the best extraction efficiency showing the presence of most of the phytochemicals in the extracts. In view of all the medicinal importance associated with the phyto-compounds found in these plant species, further investigation is encouraged in order to isolate, identify, characterize and elucidate the structures of these bioactive principles extracted and enhance their potentials for industrial and pharmaceutical utilization.

\section{Competing Interests}

The author declared that no conflict of interest exists in this publication.

\section{How to Cite this Article:}

O. Popoola, "Phytochemical Status of Different Solvent Extracts of Anthocleista djalonensis A. Chev Leaves", Int. Ann. Sci., vol. 8, no. 1, pp. 62-69, Aug. 2019. doi:10.21467/ias.8.1.62-69

\section{References}

[1] O. P. C. Ugwu, O. F. C. Nwodo, P. E. Joshua, A. Bawa, E. C. Ossai, and C. E. Odo, "Phytochemical and Acute Toxicity Studies of Moringa oleifera Ethanol Leaf Extract'. International Journal of Life Science, Biotechnology, and Pharmaceutical Research, vol 2, no 2, pp 66-71, 2013.

[2] C. Adonu Cyril, P. C. O. Ugwu, C. O Esimone, E. C. Ossai, A. Bawa, A. C. Nwaka, and C. U. Okorie, 
Popoola Oluwaseyi O, Int. Ann. Sci.; Vol. 8, Issue 1, pp: 62-69, 2020

"Phytochemical Analyses of the Methanol, Hot water and n-Hexane Extracts of the Aerial Parts of Cassytha filiformis (Linn) and Leaves of Cleistopholis patens (Benth)". Research Journal of Pharmaceutical, Biological and Chemical Sciences, vol 4, no 2, pp 11431149, 2013.

[3] M. Linga Rao, and N. Savithramma, "Phytochemical Studies of Svensonia hyderobadensis (Walp.) Mold: A Rare Medicinal Plant". Der Pharmacia Lettre, vol 3, no 4, pp 51-55, 2011.

[4] R. N. S. Yadav, and M. Agarwala, "Phytochemical Analysis of Some Medicinal Plants". Journal of Phytology, vol 3, no 12, pp 10-14, 2011.

[5] F. M. Porsche, D. Molitor, M. Beyer, S. Charton, C. Andre and A. Kollar. "Antifungal Activity of Saponins from the Fruit Pericarp of Sapindus mukorossi against Venturia inaequalis and Botrytis cinerea. Plant Disease, vol 102, no 5, pp 991-1000, 2018.

[6] G. Dong, H. Liu, X. Yu, X. Zhang, H. Lu, T. Zhou, J. Cao. "Antimicrobial and Anti-Biofilm Activity of Tannic Acid against Staphylococcus aureus. Natural Product Research, vol 32, no 18, pp 2225-2228, 2018.

[7] K. R. V. Kurapati, V. S. Atluri, T. Samikkannu, G. Garcia and M. P. N. Nair. "Natural Products as Anti-HIV Agents and Role in HIV-Associated Neurocognitive Disorders (HAND): A Brief Overview. Frontiers in Microbiology, vol 6, pp 1444, 2016.

[8] P. O. Souza, S. E. Bianchi, F. Figueiro, L. Heimfarth, K. S. Moresco, R. M. Goncalves, J. B. Hoppe, C. P. Klein, C. G. Salbego, D. P. Ge;aom. V. L. Bassamo, F. A. Zanotto, J. C. F. Moreira. "Anticancer Activity of Flavonoids Isolated from Achyrocline Satureioides in Gliomas Cell Lines. Toxicology In Vitro, vol 51, pp 2333, 2018.

[9] J. J. F. E. de Wilde, Novitates Gabonenses 73. "A new species of Anthocleista (Gentianaceae) from Gabon". Blumea, vol 56, pp 1-3, 2011.

[10] C. J. Okenwa, O. R. Chikelu, and C. E. Nwogbo. "Phytochemical, Proximate and Total Antioxidant Analysis of Ogbu (Ficus exasperata) and Uvuru (Anthocleista djalonensis) Healthygreen Leaves". International Journal of Pharmacy and Medical Sciences, vol. 5, no. 2, pp. 48-53, 2015.

[11] A. S. Okoli, C. U. Iroegbu, "Evaluation of extracts of Anthocleista djalonensis, Nauclea latifolia and Uvaria afzalii for activity against bacterial isolates from cases of non-gonococcal urethritis". Journal of Ethnopharmacology, vol 92, no 1, pp 135-144, 2004.

[12] A. A. Aiyeloja, O. A Bellow, "Ethnobotanical potentials of common herbs in Nigeria: A Case study of Enugu State". Educational Research and Review, vol 1, no 1, pp 16-22, 2006.

[13] G. Ateufack, T. B. Nguelefack, H. K. Wabo, P. Tane, A. Kamanyi, "Antiulcerogenic activity of 1-hydroxy-3,7,8trimethoxyxanthone isolated from the methanol extract of Anthocleista vogelii PLANCH. in rats". Ulcers, 2014.

[14] N. N. Azwanida, "A Review on the Extraction Methods Use in Medicinal Plants, Principle, Strength and Limitation". Medicinal and Aromatic Plants. vol 4, no 3, pp 196, 2015.

[15] J. B. Harborne, "Phytochemical methods: a guide to modern techniques of plant analysis". 2nd Edition. Chapman and Hall, London. p. 113, 1984.

[16] B. O. Mbaebie, H. O. Edeoga, and A. J. Afolayan, "Phytochemical analysis and antioxidants activities of aqueous of stem bark extract of Schotia latifolia Jacq".
Asian Pacific Journal of Tropical Biomedicine, vol 2, no 2, pp 118-124, 2012.

[17] L. N. Madike, S. Takaidza, and M. Pillay. "Preliminary phytochemical screening of crude extracts from the leaves, stems, and roots of Tulbaghia violacea". International Journal of Pharmacognosy and Phytochemical Research, vol 9, no 10, pp 1300-1308, 2017.

[18] M. J. Ajuru, F. W. Nmom, D. O. Ofa, "Qualitative and quantitative phytochemical screening of some species of Lamiaceae in Rivers State, Nigeria" Research Journal of Food and Nutrition, vol 2, no 1, pp 28-37, 2018.

[19] U. Yaqoob, I. A. Nawchoo, M. Ahmad, "Phytochemical Evaluation of Various Solvent Extracts of the Leaves, Fruits and Shoots of Ferula Jaeschkeana Vatke". Herbal Medicine, vol 2, no 3, 2016. doi: 10.21767/24720151.100019.

[20] N. Sheikh, Y. Kumar, A. K Misra. and L. Pfoze, "Phytochemical screening to validate the ethnobotanical importance of root tubers of Dioscorea species of Meghalaya, North East India”. Journal of Medicinal Plants Studies, vol 1, no 6, pp 62-69, 2013.

[21] G. N. Anyasor, K. O. Ogunwenmo, O. A. Oyelana, and B. E. Akpofunure, "Phytochemical constituents and antioxidant activities of aqueous and methanol stem extracts of Costus afer Ker Gawl. (Costaceae)". African Journal of Biotechnology, vol 9, no 31, pp 4880-4884, 2010.

[22] P. Garg, and R. Garg, "Qualitative and quantitative analysis of leaves and stem of Tinospora cordifolia in different solvent extract". Journal of Drug Delivery and Therapeutics, vol 8, no 5, pp 259-264, 2018.

[23] D. Ibrahim, I. Muhammad, S. Ashiru, I. Sani, K. Shehu, A. A. Aliero, R. U. Aliyu, "Qualitative and quantitative phytochemical screening of Mimoso pudica plant extracts (Touch Me Not)". American Journal of Biological Chemistry, vol 2, no 2, pp 8-16, 2014.

[24] K. Chigayo, P. E. L. Mojapelo, S. Mnyakeni-Moleele, J. M. Misihairabgwi, Phytochemical and antioxidant properties of different solvent extracts of Kirkia wilmsii tubers. Asian Pacific Journal of Tropical Biomedicine, vol 6, no 12, pp 1037-1043, 2016.

[25] O. A. Sodipo, J. A. Akiniyi, and U. S. Ogunbano, "Studies on certain characteristics of extracts of bark of Pausinystalia johimbe and Pausinystalia macroceras (K.Schum.) Pierre ex Beille”. Global Journal of Pure and Applied Sciences, vol 6, no 1, pp 83-87, 2000.

[26] E. O. Farombi, and A. Fakoya, "Free radical scavenging and antigenotoxic activities of natural phenolic compounds in dried flowers of Hibiscus sabdariffa". Molecular Nutrition and Food Research, vol 49, pp 1120-1128, 2005.

[27] H. Wang, T. Liu, Y. Chen, D. Shiuan, "Protective effect of freeze-dried extract of vegetables and fruits on the hydroxyl radical-mediated oxidative damage of DNA and decrease of erythrocytes deformability". Applied Biochemistry and Biotechnology, vol 141, no 2-3, pp 241-249, 2007.

[28] K. N. Agbafor, N. Nwachukwu, "Phytochemical analysis and antioxidant property of extracts of Vitex doniana and Mucuna pruriens". Biochemistry Research International, 2011. Article ID 459839.

[29] T. P. Cushnie, B. Cushnie, A. J. Lamb, "Alkaloids: An overview of their bacterial, antibiotic-enhancing and antivirulence activities". International Journal of Antimicrobial Agent, vol 44, no 5, pp 377-386, 2014. 
[30] K. Bonjean, M. C. De Pauw-Gillet, M. P. Defresne, P. Colson, C. Houssier, L. Dassonneville, C. Bailly, R. Greimers, C. Wright, J. Quetin-Leclercg, M. Tits, and L. Angenot. "The DNA intercalating alkaloid cryptolepine interferes with topoisomerase II and inhibits primarily DNA synthesis in B16 melanoma cells". Journal of Ethnopharmocology, vol 37, no 15, pp 5136-5146, 1998.

[31] D. Krishnaiah, T. Devi, A. Bono, and R. Sarbatly. "Studies on phytochemical constituent of six Malaysian medicinal plants". Journal of Medicinal Plant Research, vol 3, pp 67-72, 2009.

[32] Y. L. Lee, G. W. Huang, Z. C. Liang, and G. L. Mau. "Antioxidant properties of three extracts from Pleurotus citrinopileatus". LWT-Food Science and Technology, vol 40, no 5, pp 823-833, 2007

[33] N. Ozsoy, A. Can, R. Yanardag, N. Akev. "Antioxidant activity of Smilax excelsa L. leaf extracts". Food chemistry., vol 110, no 3, pp 571-583. 2008

[34] H. P. S. Makkar, T. Norvsambuu, S. Lkhagvatseren, and K. Becker. "Plant secondary metabolites in some medicinal plants of Mongolia used for enhancing animal health and production". Tropicultura, vol 27, no 3, pp 159-167, 2009.

[35] G. Fu, H. Pang, and Y. H. Wong. "Naturally occurring phenylethanoid glycosides: potential leads for new

\section{Publish your books with AIJR publisher- \\ $\checkmark \quad$ Publish with ISBN and DOI. \\ $\checkmark$ Publish Thesis/Dissertation as Monograph. \\ $\checkmark$ Publish Book Monograph. \\ $\checkmark$ Publish Edited Volume/ Book. \\ $\checkmark$ Publish Conference Proceedings \\ $\checkmark$ Retain full copyright of your books.}

Submit your manuscript at books.aijr.org therapeutics". Current Medicinal Chemistry, vol 15, no 25, pp 2592-2613, 2008.

[36] H. V. Nobre-Junior, F. D. Maia, R. A. de Oliveira, M. A. M. Bandeira, C. Pessoa, M. O. Moraes, G. M. A. Cunha, G. S. B. Viana. "Neuroprotective actions of tannins from Myracrodruon urundeuva on 6-Hydroxydopamineinduced neuronal cell death". Journal of Herbs, Spices, and Medicinal Plants, vol 13, no 2, pp 41-57, 2007.

[37] R. S. Rosenberg Zand, D. J. Jenkins, E. P. Diamandis. "Flavonoids and steroid hormone-dependent cancers". Journal of Chromatography. B Analytical Technologies in the Biomedical and Life Sciences, vol 777, no 1-2, pp 219-232, 2002.

[38] S. A. Aherne, N. M. O'Brien. "Dietary flavonols: chemistry, food content and metabolism". Nutrition vol 18, no 1, pp 75-81, 2002.

[39] G. G. Duthie, S. J. Duthie, J. A. Kyle. "Plant polyphenols in cancer and heart disease: implications as nutritional antioxidants". Nutritional Research Reviews, vol 13, no 1, pp 79-106, 2000.

[40] P. Knekt, R. Jarvinen, A. Reunanen, J. Maatela. "Flavonoids intake and coronary mortality in Finland: a cohort study". British Medical Journal, vol 312, no 7029, pp 478-481, 1996.
Publish your research article in AIJR journals-

$\checkmark \quad$ Online Submission and Tracking

$\checkmark$ Peer-Reviewed

$\checkmark$ Rapid decision

$\checkmark \quad$ Immediate Publication after acceptance

$\checkmark$ Articles freely available online

$\checkmark$ Retain full copyright of your article.

Submit your article at journals.aijr.in 